theory, do form the main motor for most actions. Our general scientific disregard for the 'lower' emotions as explanatory factors is more expressive of our own culture and our academic subculture, than of the religion of our fellow men. Of course, the affluent West can afford to look for the elated feelings of religiosity, nicely ordered wordviews, and coherent belief systems. But in the great majority of societies studied by anthropologists survival is the key word. Harsh surroundings, a merciless physical environment, droughts and famines all take their toll. Hobbes's picture of 'brutish, nasty and short' is an inappropriate description of tribal life surely not to be invoked. On the other hand, Rousseau's noble savage is widely off the mark too. Any field anthropologist knows from his own experience the quiet harmony a rural village offers him. Most of us long to go back to the field, if only for that reason. But as visiting scientists we really have the best of two worlds, the security and-medical-technology of the West and the intensive social interaction of the face-to-face community.

Recently an anthropologist, after having broken his leg in remote Nepal, was flown out by helicopter. No doubt his Sherpa friends were better adapted to the mountains, less clumsy on the steep slopes to say the least, and would not slip as easily; still, they must solve their own problems in their own way, by their own means, and would never in their lifetime be able to send for a helicopter. (Oral communication).

What has this to do with his religion? Well, religion is an important facet of the cultural array of problem-solving devices, either for big calamities or for small nuisances. Wallace, one of the main proponents of this view on religion, cites a charming example:

A Cherokee burning himself, blows fresh water in four parts on the burn recting: Water is cold, ice is cold, snow is cold, rime is cold. "Relief" I will be saying (Wallace 1966: i17).

Another case comes from our own field experience:

A Kapsik1 suffering from headache whirls a discarded potsherd three times around his aching head, and throwing the potsherd away sighs: "Well, that is fixed" (Van Beek 1978: 378$)$.

\section{Religion and personality}

Bigger problems call for stronger measures. Long before LéviStrauss focussed attention on the efficacité symbolique (1958), the role of religious therapy in healing the hodge-podge of so-called psychosomatic illnesses had been acknowledged (e.g., Gillin 1948). Following C.G. Jung's distinction between anima and persona, Wallace (1966) distinguished social personality (persona) and self image ( \pm anima). The social identity of a person forces him in a mould in which several personality traits have to be suppressed. One's self image and one's public personality are never identical. In some cases the discrepancy between both can cause a serious clash. The self-image, the weaker of the two, suffers heavily and disillusionment or neurosis results. Now, religion can solve this problem by offering some strong, viable models for personality with which one may identify at least for a short time. Three points are stressed here by Wallace: some psychic problems are normal in any culture and, second, each culture has its own brand of problems as well as its own version of normality; definition of mental-or even somatic-illness is culture-relative. Third, some phases in life are more problem-prone than others. Of course religion is not a panacea for all problems, but it sometimes does quite a lot. In ritual people are liberated from the strains their social personality imposes on them, resulting in a healthy catharsis.

The discussion on this issue centers on the question of the shaman. Someone who enters trance easily or with the help of drugs and who in helping clients helps himself too - should he be considered 'psychotic,' 'abnormal' or whatever ethnocentric label western observers may want to attach? In the eyes of many observers the shaman shows himself an unstable neurotic person who needs his trance to stay well. In Wallace's terms: a shaman needs regular reidentification with the religious personality model, as his self-image is decidedly at odds with the rights and duties assumed from his social personality. No artic bysteria nor any pathological illness, but a relativistic personality conflict. In many respects moreover, shamans are as able farmers, merchants, hunters, or fishermen as any of their compatriots.

Silverman (1967) underlines that there is no reason why shamans should have the same personality traits in all cultures. So Wallace may be 
right, even if mental defects should not be disregarded so easily. Kennedy (1973) neatly sums up this discussion. Some anthropologists harbour the view that shamans are superbly endowed individuals who have the valuable capacity to put themselves to trance. Castaneda's Don Juan (Castaneda 1968) would have been a splendid example but for the small detail that this material seems to be a fake (de Mille 1980).

Religion, however, is not reserved for special individuals such as shamans; ordinary individuals, too, meet their needs by religion, so in other aspects of religion the expression of not specifically pathological personality traits should be discernible. As an example Spiro's work on the Ifaluk can serve; any society has to build in safety valves for individuals and the Ifaluk society has a lot of inbuilt stress with which the inhabitants have to cope.

Ifaluk is a small Micronesian Island where a few hundred people live at close quarters. All arable land is under cultivation and no population expansion is possible. Living hemmed in like this, Ifaluk have to have a device to get rid of their frustrations, aggression or any kind of negative feeling. Their solution is a supernatural scapegoat. Alus, spirrts are the core of their belief system, and these alus are responsible for anything bad. People hate the spirits, venting agression on them in a way they could never do on their fellowmen. Thus living in disharmony with their supernatural world they can afford to live in harmony with their living kinsmen (Spiro 1952 ).

\section{Religion and socialisation}

One drawback of this elegant reasoning is that it is just ad boc reasoning, and anthropology should not content itself with just explaining the status quo. In the I95os and 1960s a score of researchers and theorists addressed themselves to the problem how an individual is situated in his culture. Most of these researches do not center on religion, as from a theoretical and practical point of view personality development and childhood training are more important. Still, in nearly all studies, religion does play a part. Early stimulus in this direction came from Kardiner and Linton (1945) who developed a scheme of factors influencing personality development, which stimulated some new ap- proaches. Du Bois's Alor study (1944) is the best known of these. In this approach religion is interpreted as a projective system, in which all kinds of residual fears from early childhood may be sublimated on the one hand, and on the other hand training practices and concomitant sociopolitical organisation find a direct expression.

Theoretical and methodological systematisation has come from Whiting and Childe in whose view (I953) a culture consists of a maintenance system comprising the basic economic, political, and social organisation. This system is for a large part responsible for the child rearing system, which in its accord shapes 'modal personality' - the standard or desired personality in that particular culture. This personality is a major factor in shaping the projective systems, like art and religion. Whiting and associates set up a huge comparative framework in which half a dozen coordinated field studies were undertaken to be compared later (Whiting and Childe 1953), one of the biggest research endeavours anthropology has ever known. Religious processes feature prominently in the statistical worldwide comparisons that the research team has done. Using a well-known standard sample of all the world cultures, part of the so-called Human Relations Area Files (see Murdock 1969) they extensively checked their theoretical options in operationalised testable propositions. One example: Whiting's neo-Freudian theory postulates a correlation between late weaning and harsh male initiation ceremonies. The reasoning is as follows: Late weaning favors a long post partum sex taboo, which incites the husband to have plural wives. This implies virilocality (residence of the couple at the husband's place), resulting in a fixed core of patrilineally related men. The child has a strong motherbond and will see the father as a rival. Control of insurgent sons can be effected by puberty rites, so this cultural Oedipus situation leads, to harsh initiation rituals, to keep the sons in line.

This proposition has been tested with quite positive results. Other projective elements in religion put to the test were interpretations of illness, witchcraft beliefs and accusations, and danger or benevolence in the supernatural world (resp. Whiting and Childe 1953; Spiro and d'Andrade 1958; Lambert, Minturn, Triandis and Wolf 1958).

At the end of the 1960 s these studies changed direction; maybe they 
had run their course. Anyway, Whiting and Childe's massive research program clearly showed that their strict developmental approach yielded only limited results. Thus, one of the major conclusions of the famous Six Cultures study (Whiting and Childe 1953) was that the differences in child rearing within one culture surpass the difference between the modal educational ways. So the theory correctly predicts correlations, but those are not overly important. Reliability and validity are high, relevance low. Moreover, other interpretations of the same phenomena are possible.

\section{Religion and social organisation}

The covariance of social and religious matters, does not need a personality development scheme as a mediating factor; those correlations can quite easily be explained by the direct dependency of religion on its sociocultural foundation. In fact, this is the leading hypothesis of most of the British anthropological studies of religion, as Jackson shows. The comparative approach, however, is quite feasible too. Young (1962, 1965) showed that the correlation between virilocality and harsh initiation rites can be explained straightaway by pointing at the ways in which 'male solidarity' is organised and has to perpetuate itself. Cohen (1964) using the same approach pointed at the duties and responsibilities of unilineal groups, which necessitate certain ways of initiating boys and girls. The belief system, another projective part of religion, shows considerable covariation with social organisation regardless of child rearing practices. Swanson (1960) showed in another cross-cultural survey how monotheism, polytheism, witchcraft beliefs, and belief in reincarnation were tied in with social variables like level of state formation, social classes, bride prices, and war.

However, the main tide of anthropology has not been in crosscultural surveys, however fascinating they may be. Thorough and penetrating analyses of individual cases-always the stronghold of anthropology-yield more insight into religious processes and cultural covariation.

\section{General views of religion}

A trend towards a more philosophical but still individualistic way of looking at religion can be spotted in several countries. Tying in with the above mentioned theories $\mathrm{La} \mathrm{Barre}$, in a giant volume on prophetic movements (La Barre 1972), tries to unravel the 'origins of religion.' For $\mathrm{La}$ Barre a religion starts in a prophetic movement, as the source from which all religion springs lies deep within each and'every one of us, to be tapped by someone more fully aware of it than most, a prophet, seer, or revelator. Religion, in his view, is essentially part of the deep, noncharted areas in human experience. Religion is the human way to explain our participation in the unknown. A new religion springs from dreams, dramatic individual experiences, which are interpreted by the dreamer and accepted by groups of people.

Van Baal, in a series of major works on the theory of religion, starts from an existential standpoint (Van Baal 1947, 1971, 1981). Man is a strange phenomenon; he has the unique capability of observing not only the external world around him, but also himself, even his own processes of observation. In this he is out-of-this-world, alien and definitely a stranger. However, at the same time he is very much part of this same universe, part and parcel of his world. Man is subject and object, both stranger and friend. He is a subject longing for participation, longing for a partner. Religion, being an ascriptive way of thinking, is a way to partnership with the universe and the expression of the human condition. Symbols are the means of communication with this universe, which in itself is a cultural creation, imposed upon man by his society.

This approach closely resembles Turner's use of the term communitas (1969). Turner discerns two trends in human culture, the first focussing on organisation, with fixed positions, roles, and slots making up the social persona, and the other viewing society as a homogeneous community of idiosyncratic individuals who, despite external differences, all share a common humanity. This latter he calls communitas: the tendency towards integral humanity. This trend is emphasized in ritual, like in the installation of chiefs, who during the installation ritual are imbued in communitas to impress their duties towards the common people upon them. Thus any religion results from a dialectic between individualism 
and group membership, in which the former has an ethical superiority over the latter, a point mentioned also by Schoffeleers (Schoffeleers and Meyers 1978).

Two other areas of anthropological interest in religion are prominent at the moment. One is the broad specter of conflict, protest, etc., the other the ecological approach to anthropology.

\section{Religion and confict}

Each society has its own tensions and problems which may show in religion. One favorite - i.e., for anthropologists - expression of problems and conflicts is witchcraft. Rituals of rebellion (Gluckman I954, Norbeck $1_{96}$ ) are another way of expressing inherent insoluble conflicts. In both cases the reasoning closely follows the psychological tracks indicated above: the ritual, beliefs or accusations serve as a safety valve, and perform a catharsis for the society, which by playing on inherent contradictions makes those tolerable, thus preserving the status quo of society. However, in the long run this kind of catharsis, can have a negative effect too, as Wallace showed in his Iroquois example:

The Iroquois channeled aggressive tendencies by means of the so-called Condolence Ceremony, towards other tribes; the Ceremony eliminated intratribal warfare and thus made intertribal warfare possible. However, the retaliation invoked by the surrounding tribes at the end decimated the Iroquois and nearly obliterated them as a tribal unit (Wallace 1966: 205-286).

Conflict, tension or protests often are invoked whenever anthropologists treat new religious movements. The literature on these is very vast but surveys are available (Wilson 1973, La Barre 1972, Köbben 1959). Most authors relate the new movement to some external influence, which plays hazard with the traditional ways of life. Balandier (I955) considers the colonial situation the main factor, the religious movement being a reaction against it: the only way in which people can regain the initiative, the only vertical social mobility, the only escape out of the system. A protest against social inequality Köbben calls it, and
Van Baal coins the term 'erring acculturation' explaining cargo cults as reaction to a thoroughly misunderstood cultural change. However, not all evaluations are negative; Balandier argues that this kind of movement really does give some 'reprise d'initiative,' Redfield sees it as a creative moment in culture (Redfield 1968) and Wallace uses the most positive term of all: cultural revitalisation. When the old structures have crumbled and the old culture is irrevocably lost, a prophetic movement can be a vigorous and positive factor in readjusting people to the new surroundings. Goodenough (1960) even advises development agents to ride the prophetic movement in their community development projects! Not all anthropologists would dare to go that far!

A recent development in these studies is the use of neo-marxist terminology. The main factors of change are conceived in terms of mode of production, productive forces, and the articulation of production. This materialistic approach is counter-balancing the recent trend in anthropology (see Oosten) towards cognitive studies, quite a dichotomy one might say! Materialism states that the societal superstructure reflects the clash of interests in the infrastructure and shields real conflicts from detection. Power structures are hidden by the ideological representation, thus preserving these very powers intact. Works by Werbner (1977), van Binsbergen (1979) and Schoffeleets (1982) exemplify this trend. In a way Burridge's ( 1969$)$ treatment of millenarian activities fits in too. In his view religion primarily is a set of ideas about power, the ordering and distribution of it: where power structures break down, a millenarian prophet can construct new ways of dealing with power, creating a new power order.

\section{Religion and the ecosystem}

The second topic is just as materialistic. Religious rituals have other functions besides therapy, group cohesion, or catharsis; they have an ecosystemic function too. Ritual especially may serve as an ecological instrument. In several ways this can be shown. First ritual can be instrumental in shaping group consensus. Divination as a way of decision making is one example. Decision making is an important part of 
any production system: fields have to be sown, gardens cleared, trees cut down. What specific fields, trees, or gardens are to be treated is indicated by divination, the authority of the supernatural world guaranteeing a quick and easy consensus. In many instances the fact of deciding is more important than what decision is taken. If Sheridan's ass could have consulted a diviner, it would never have starved. Vogt (1952) draws attention to this aspect, to explain the persistence of the water witching practice in the USA. Scientific information on water availability is couched in probability terms, the-objectively-slightly less dependable water witching answers in clear terms, thus giving the farmer confidence in his labour intensive well digging. Divination can help in other ways too. Moore (1957) points at the problems of a Naskapi caribou hunter, who has no way of knowing the next caribou migration route as this changes every year. His safest means is, according to Moore, to randomise his hunting sprees in order to avoid over-hunting of an area and scaring the caribou away. Divination does just that. The Naskapi shoulder blade divination precludes patterning; human thinking always repeats itself, the cracks in the shoulder blade form a truly random indication.

In Harris's well known analyses (see Bibliography) ritual plays an even more crucial role. His goal is to disprove the independence of religion, by showing how it is tied in with the general ecology of the group. So he jumps into any case in which the people's life seems to be governed by religion. Starting with the abimsä (non-violence) rule in India, Harris ( 1966 ) shows that the taboo on slaughter of cattle in India does not represent a classic case of protein waste in a poor community, but in fact is a needed protection of the cow, i.e., of agriculture. Cattle are so important for Indian agriculture that the no-slaughter rule is eminently feasible. Besides, cattle do not compete with humans for food; cows are scavengers in India, a useful niche anywhere. A 'naturally selected ecosystem' Harris calls this case, and the same could be said of the other instances in which the independent influence of religion on the economy has been reported. These range from pig-hating Middle Eastern cultures to pig-loving Melanesian tribes, from wife-beating Yanomamö to man-eating Aztec (Harris 1974). In all these cases the seemingly irrelevant taboos, the strange customs and curious practices stem from the ecology and on close inspection fit into the ecosystem. Of course a lively discussion resulted from Harris's somewhat simplistic allencompassing theory building. Douglas (1973), of course, has a very different opinion on the origin of the pig taboo (see Jackson's paper); on the Indian case Harner gives at least a more balanced interpretation (1967). Whenever Harris draws heavily on one ethnographer, he usually is at odds with him, as with Rappaport (Melanesia, Tsembaga Maring, 1968) and Chagnon (Yanomamö, 1969). Harris's treatment of the classic Aztec material, is heavily disputed by Sahlins (1976). In Harris's view environmental depletion, lack of protein and population regulation are among the crucial factors influencing culture and religion, while the whole complex of warfare serves as an important cultural mechanism to cope with these problems. Sahlins (1976) argues that a culture is a symbolic system of meaning and should be understood in that way. Geertz, in a fascinating series of essays (1973), tries to bridge the two approaches. At the moment the discussions are in full swing. The dichotomy between cognitive and materialistic approaches centers on Harris and will not be resolved easily.

\section{Bibliography}

Baal, J. van (1947), Over wegen en driffveren der religie. Een godsdienstpsychologische studie. Amsterdam: North-Holland.

-(1971), Symbols for communication; religion in antbropological theory. Assen: Van Gorcum. - (1981), Man's quest for partnership. The antbropological foundation of etbics and religion. Assen: Van Gorcum.

Balandier, $\mathrm{G},(1955 \%)$, Sociologie actuelle de l'A frique noire. Dynamiques des changements sociaux en Afrique Centrale. Paris: Presses Universitaires de France.

Beek, W.E.A. van (1978), Bierbroumers in de bergen. De Kapsikz en Higi van Noord Kameroen en Noord-Oost Nigeria. Utrecht: Mededelingen Inst. voor Culturele Antropologie 12.

Beek, W.E.A. van (1979), 'Traditional religion as a locus of change,' in Official and Popular religion; analysis of a thema for religious studies: 514-543. eds. Vrijhof and Waardenburg. Den Haag: Mouton. 
Binsbergen, W.M.J. van (1979), Religrous change in Zambia. Dissertation Amsterdam University.

Binsbergen, W.M.J. van and Schoffeleers, J.W.M. (1981), The social science of african religion: theoretical and metbodological explorations. (in press).

Burridge, K. (I G69), New beaven, new earth. Oxford: Clarendon.

Castaneda, H.J.M. (1962), The teachings of Don Juan: A Yaqui way of knowledge. Los Angeles: University of California Press.

Chagnon, N. (1968), The fere people. New York: Holt, Rinehart and Winston.

Cohen, Y. (1 964), The transition from childhood to adolescence. Cross-culture studies of initiation ceremonies, legal systems and incest taboos. Chicago: Aldine.

Douglas, M. (1973), Natural symbols; explorations in cosmology. Harmondsworth: Penguin Du Bois, C. (1944), The People of Alor. Minneapolis: University of Minnesota Press.

Geertz, C. (1973), The interpretation of cultures. New York: Basic Books.

Gillin, J. (1948), 'Magical fright', Psycbiatry x x: 387-400.

Gluckman, M. (1954), Rituals of rebellion in Soutb-East Africa. Manchester: Manchester University Press.

Goodenough, W.H. (1966), Cooperation in change. New York: John Wiley and Sons.

Harner, R. (1969), 'Remarks on India's sacred cattle,' Current Antbropology, 222-245. Harris, M. (1966), 'The cultural ecology of India's sacred cattle,' Current Antbropology 7 $51-66$.

- (1968), The rise of anthropological theory. London: Routledge and Kegan Paul.

- (1974), Cows, pigs, wars and witches. New York: Random House.

- (1978), Cannibals and kings. The origins of culture. New York: Random House.

- (1979), Cultural Materialism. The struggle for a science of culture. New York: Random House.

Kardiner, A. and Linton, R. (1945), The psychological frontiers of society. New York: Columbia University Press.

Kennedy, J.G. (I973), 'Cultural Psychiatry', in Handbook of Social and Cultural Antbropology. J.J. Honigmann (ed), I I 19-1 r99. Chicago: Honigmann.

Köbben, A.J.D. (1959), 'Profetische bewegingen als witing van sociaal protest.' Sociologisch jaarboek I $_{3}: 5-88$.

La Barre, W. (1972), The ghost dance. Origins of religion. London: Allen and Unwin.

Lambert, W.W., Minturn, L., Trandrs, M. and Wolf, N. (1959), 'Some correlates of beliefs in the malevolence and benevolence of supernatural beings: a cross-cultural study', Journal of Abnormal and Social Psychology ; 8: 162-169.

Lévi-Strauss, C. (1958), Anthropologie structurale. Paris: Plon.

Mille, R. de (1980), The Don Jwan papers: further Castaneda controversies. Californian Ross Erikson Publ.
Moore, O.K. (1957), 'Divination-a new perspective.' American Antbropologist 59: $69-74$

Murdock, G.P. (1969), Ethnographic Atlas. Pittsburgh: University of Pittsburgh press.

Norbeck, (1963), African rituals of conflict. American Antbropologist 65: 1 $254^{-1} 279$.

Rappaport, R.A. (1967), Pigs for the ancestors. Ritual in the ecology of a New Guinea people. New Haven: Yale University Press.

Redfield, R. (1968), The primitive world and its transformation. Harmondsworth: Penguin.

Sahlins, M. (1976), Culture and practical reason. Chicago: University of Chicago Press.

Schoffeleers, M. and Meijers, D. (1978), Nationalism and economic action. Critical questions on Durkbeim and Weber, Assen: Van Gorcum.

Silverman, D. (1967), 'Shamans and acute schizophrenia.' American Anthropologist 69: $21-3 \mathrm{r}$

Spiro, M.E. (1952), 'Ghosts, Ifaluk, and teleological functionalism,' American Anthropologist 54: 497-503.

Spiro, M.E. (1966), 'Religion: problems of definition and explanation,' in: Anthropological Approaches to the Study of Religion. ed. M. Banton, ASA 3: 85-126. London: Tavistock.

Spiro, M.E. and d'Andrade, R.G. (i958), 'A cross-cultural study of some supernatural beliefs.' American Antbropologist 6o: 456-466.

Swanson, G.E. (1960), The birth of the gods: the origin of primitive beliefs. Ann Arbor: University of Michigan Press.

Turner, V.W. (1969), The ritual process, structure and anti-structure. Chicago: Aldine.

Vogt, E.Z. (1952), 'Waterwitching: an interpretation of a ritual in a rural American community,'Scientific Monthly 75: 175-186

Wallace, A.F.C. (1966), Religion. An antbropological view. New York: Random House. Werbner, R.J. (1977), Regional Cults, ASA 26, London: Tavistock.

Whiting, J.W.M. \& Child, I.L. (1953), Child training and personality: a cross-6ultural study. New Haven: Yale University Press.

Wilson, B.R. (1973), Magic and the millennium. A sociological study of religious movements of protest among tribal and tbird world peoples. London: Heinemann.

Young, F.W. (1962), 'The function of male initiation ceremonies' a cross-cultural test of an alternative hypothesis,' American Journal of Sociology 67: 379-396.

- (1965), A cross-cultural study of status dramatization. Indianapolis: University of Indiana Press. 